This item was submitted to Loughborough's Research Repository by the author.

Items in Figshare are protected by copyright, with all rights reserved, unless otherwise indicated.

\title{
Justifying the civic interest in sport: Boltanski and Thévenot, the six worlds of justification, and hosting the Olympic games
}

\section{PLEASE CITE THE PUBLISHED VERSION}

http://dx.doi.org/10.1080/16138171.2016.1183930

\section{PUBLISHER}

(c) Taylor \& Francis

\section{VERSION}

AM (Accepted Manuscript)

\section{PUBLISHER STATEMENT}

This work is made available according to the conditions of the Creative Commons Attribution-NonCommercialNoDerivatives 4.0 International (CC BY-NC-ND 4.0) licence. Full details of this licence are available at: https://creativecommons.org/licenses/by-nc-nd/4.0/

\section{LICENCE}

CC BY-NC-ND 4.0

\section{REPOSITORY RECORD}

Giulianotti, Richard, and Tommy Langseth. 2019. "Justifying the Civic Interest in Sport: Boltanski and Thévenot, the Six Worlds of Justification, and Hosting the Olympic Games”. figshare. https://hdl.handle.net/2134/21888. 
(ORIGINAL MANUSCRIPT)

This is the Author's Original Manuscript in its final and definitive form. The Version of Record can be found via the following reference:

Giulianotti, R. and Langseth, T. (2016) Justifying the Cvic Interest in Sport: Boltanski and Thevenot, the sic worlds of justification, and hosting the Olympic Games, European Journal for Sport and Society. Available:

http://www.tandfonline.com/doi/abs/10.1080/16138171.2016.1183930

\title{
Justifying the Civic Interest in Sport:
}

\section{Boltanski and Thévenot, the Six Worlds of Justification, and Hosting the Olympic Games}

\author{
Richard Giulianotti \\ Loughborough University, United Kingdom, \\ and University College of Southeast Norway \\ and \\ Tommy Langseth \\ University College of Southeast Norway
}

\begin{abstract}
This paper examines and applies the widely influential work of Boltanski and Thévenot in order to investigate and understand political issues or disputes within sport. We provide a critical elaboration of Boltanski and Thévenot's theory of the six 'orders of worth' or 'worlds' of justification that are drawn upon by social actors within these disputes. We examine how social actors may draw upon multiple justifications (or worlds) in order to advance their positions or interests; how power differences arise between these worlds; and, how weak worlds of justification may extend their influence within specific issues. To elaborate our analysis, we discuss the public issue of Olympic bidding and hosting, and how key social actors or stakeholders (such as local and national governments, event sponsors, and sport bodies) draw on different worlds of justification, particularly in advocating the staging of these events. This issue indicates that the six worlds are organised hierarchically into three 'levels of worth': the market, fame, and domestic worlds are the most prominent, while civic world arguments have least influence. These power differentials are reflected further in the criticisms and compromises that arise between the civic world and other worlds.
\end{abstract}


We conclude by examining how civic world justifications may be accorded greater prominence within sport and other public issues such as those relating to Olympic bidding and hosting.

Keywords: Sport; Olympics; civic world; dispute; justification; levels of worth

\section{Introduction}

The work of Luc Boltanski and Laurent Thévenot has been at the forefront of new French pragmatic sociology, and has been widely influential in diverse theoretical and substantive fields in social science in recent years. ${ }^{1}$ Boltanski and Thévenot's most significant publication - On Justification: The Economies of Worth (2006) - focuses on disputes and justifications in social life: that is, those 'critical moments' when public issues arise and are disputed by different social actors (cf. Boltanski and Thévenot, 1999, 359-360). At the heart of this paradigm is their analysis of the six specific types or 'worlds' of justification that social actors draw upon during disputes. The interplay of these worlds produces diverse matrices of conflict, compromise or collaboration in different situations.

Three interrelated questions arise in relation to Boltanski and Thévenot's model. First, how are these worlds marshalled by particular social actors in relation to specific public issues? Second, how do power differences arise between these worlds, to establish stronger or weaker forms of justification? And third, how might relatively weak worlds of justification gain stronger positions vis-à-vis the others within disputes?

We seek to answer these questions by elaborating and applying Boltanski and Thévenot's theory within the field of sport. We focus upon one illustrative public issue: bidding for and hosting the Olympic Games, particularly in relation to the London 2012 Olympics. We critically extend Boltanski and Thévenot's model by identifying specific hierarchies that take shape between and across these different worlds of justification. We highlight how greater weight may be given to civic interests (or the 'civic world') that are otherwise marginalised within sport and other disputes. Our resulting theoretical elaboration of Boltanski and Thévenot's model may be used to underpin empirical research in sport and other social fields. Save for some noteworthy brief mentions, Boltanski and Thévenot have been largely ignored by sociologists of sport, hence our broader aim is also to introduce this paradigm to the sub-discipline (cf. MacRury, 2009, 53, 61).

Our discussion is organised into four main parts. First, we provide a contextual discussion on Boltanski and Thévenot and our use of evidence from Olympic bidding and hosting. Second, we summarise Boltanski and Thévenot's six 'orders of worth' and discuss how each is utilised in justifications for Olympic bidding and hosting.

\footnotetext{
${ }^{1}$ See for example the large volume by Susen \& Turner (2014); papers by Pecoraro \& Uusitalo (2014), Nielsen (2014) and Karsenti (2014); special issues of European Journal of Social Theory (2011) and Thesis XI (2014), devoted to Boltanski's work; and, several heavily-cited translated texts (Boltanski \& Thévenot 2006; Boltanski \& Chiapello, 2007; Boltanski, 2011, 2012).
} 
This discussion is suitably detailed in order to provide the basis for, third, our critical extension of the theoretical framework of Boltanski and Thévenot wherein we identify three levels of power that differentiate these six worlds in public issues such as Olympic bidding and hosting. Fourth, we examine the conflicts and compromises that arise between these worlds with particular reference to the position of the 'civic world'. We conclude by exploring how civic justifications may be accorded greater prominence within disputes such as those relating to Olympic bidding and hosting.

\section{Boltanski and Thévenot, and the Six Orders of Justification}

Boltanski and Thévenot have been heavily associated with French 'pragmatic sociology', which developed from the 1980s onwards, and has also featured leading scholars such as Bruno Latour, Michel Callon and Michelle Lamont. Pragmatic sociology stands in 'stark contrast' to the 'critical sociology' of Pierre Bourdieu, under whose tutelage Boltanski had initially worked in the early 1970s (Bokker, 2011, 252). Boltanski $(2011,20)$ came to criticise Bourdieu's critical sociology for presenting social agents as uncritical 'cultural dopes', as dominated without knowing it, and for assuming that only sociologists are able to see how people are subjugated by social structures and processes (Boltanski, 2011, 20). In marked contrast, Boltanski advocates a 'pragmatic sociology of critique' which 'fully acknowledges actors' critical capacities and the creativity with which they engage in interpretation and action” (Boltanski, 2011, 43; cf. Bénatouïl, 1999). Thus, the sociologist cannot, and should not, hark back to a priori definitions of power and interest that govern social actions. Instead, the sociologist must reintegrate the capability of critique into the social world, and show how actors draw upon different logics in different situations to direct their actions, arguments and agreements within and through particular disputes.

For Boltanski and Thévenot, the object of sociological inquiry is not the social actor or the social structure, nor some kind of relationship between the two. It is instead the situation, and different situations will call upon different regimes of action (Boltanski \& Thévenot, 1999). Of most importance is the 'regime of justification'; that is, a regime of action when there is some kind of disagreement and where actions need to be justified. In seeking to advance justifiable arguments, social actors also make reference to 'the common good': that is, a principle which is 'superior to persons and can institute equivalence among them' (Boltanski, 2012, 14).

The 'situation-transcending element' in pragmatic sociology centres on Boltanski and Thévenot's (1999, 2006) identification of six self-enclosed 'orders of worth' or 'worlds' that are drawn upon by social actors in disputes: specifically, these are the civic, inspired, domestic, fame, market and industrial worlds (Blokker, 2011, 253). We might note here that Boltanski and Thévenot's six-world framework has been extended by other scholars to produce further worlds, such as the green and projectoriented worlds (Thévenot, Moody \& Lafaye, 2000; Boltanski \& Chiapello, 2005a). 
Here, we have elected to focus on the original six-world framework for four main reasons: the need to retain appropriate brevity for a journal article, which confines us to six rather than more worlds; our concern in part to introduce and to extend critically the original six-world framework proposed by Boltanski and Thévenot; our recognition that the existence of some of these other worlds, such as the green world, is disputed; and, our view that important aspects of these further worlds may be effectively incorporated back within the existing six-world framework - for example, as we indicate later, in the case of the London 2012 Games, aspects of the green 'world' may be encompassed within the industrial and civic worlds.

The six worlds of justification must not be understood as social worlds or lifeworlds, but are instead more comparable to discourses, rationalities or logics. In identifying and elaborating these worlds, Boltanski and Thévenot rely on three different sources. First, they investigate the kinds of argument that are present empirically in everyday disputes. Second, they utilise classical political philosophy in order to map the grammar at work in each world, and to frame the types of argument found in everyday disputes. The third source is management texts and "how-to" guides, which the authors use to pin down the objects, subjects and relations within each world.

Each world is revealed when situations of dispute and compromise occur. Boltanski and Thévenot (2006) explain that each world pursues different criticisms and compromises towards the other worlds. One prominent compromise has centred on the market and industrial worlds, whereby the pursuit of profit is combined with efficient production. Social actors in complex societies may draw on several of these worlds, for example when acting as citizens (civic world), consumers (market world), or family members (domestic world). In addition, we may consider the possibility that social actors do not have a singular connection to a specific world, but will appeal to several worlds in order to advance their arguments and interests. Thus, for example, in professional sport organisations, the marketing divisions may refer to all six worlds (inspiration, fame, civic, domestic, market, and industrial), to present their athletes as creative, famous, fan-orientated, family-friendly, highly marketable, and hard-working. In this context, key issues relate to how some of these justifications are more contested than others; and, how some of these worlds rather than others are combined to advance particular interests. However, some of these justifications rather than others will be prioritised; some justifications rather than others will also be substantially challenged by different social actors.

The staging of the Olympics by cities and nations is certainly a major public issue. Social actors who advocate bidding for and hosting these events would be expected to forward diverse types and mixes of justification from across different worlds. On the other side, opponents of hosting these events point to a number of issues, such as their high financial costs, for example with the estimated US $\$ 50$ billion bill for the 2014 Sochi Winter Olympics; widespread civic opposition, as evidenced by the 2013 protests and riots in Brazil, host of the 2014 football World Cup finals and 2016 Olympics; and, the wasteful legacy of 'white elephant' facilities, such as the 
derelict sport venues that staged the Athens 2004 Games (Reuters, 21 February 2014; The Guardian, 21 June 2013; Lenskyj 2008; The Guardian, 9 May 2012).

Applying the framework of Boltanski and Thévenot to the Olympics helps us to understand how key social actors or stakeholders draw on different logics in order to justify their positions on a specific public issue in sport or more widely. In the Olympic case, by key actors or stakeholders, we mean local and national governments, sport federations, bid committees, corporate sponsors and supporters, and any community groups; in the specific Olympic Games that we consider, most of these stakeholders support bids to host these events. Analysis of Olympic bidding and hosting enables us to identify the interplays and underlying hierarchies of these different worlds; and also, to explore how different stakeholders seek to establish themselves and their interests by utilising prominent arguments that are drawn from particular worlds. In so doing, our "case” is not London 2012 as an event per se, but the justifications various agents use in regard to the bidding and hosting of the Games. In other words, the empirical example that we use must be seen as a theoretical construct in which the agents' own constructions are taken into consideration. Even though our case can be seen as theoretically constructed, it is our concern that the case should also allow us to critically extend theory.

Our discussion of these Olympic issues draws on data that was collected and analysed in two stages. First, we examined official documents and reports by key organisations, media reports, and, popular and academic texts, with respect to London 2012 and, to a lesser extent, other Olympic Games. Data from the mass media was drawn from three major UK sources: BBC online news services, and left-liberal The Guardian and conservative The Telegraph newspapers, enabling us to canvass daily broadsheets that are largest-selling at either end of the political spectrum. Other media sources, such as the Daily Mail or Financial Times, are drawn on at times to elaborate our arguments. We also draw on several key documents from the public and private sectors - notably DCMS (2012), Goldman Sachs (2012), and HM Government/Mayor London Office (2013) - which, importantly for this study, addressed the impacts and legacies of the London 2012 Games. Supplementary data sources are provided by academic and other books and articles on the Olympics. These documents, media reports, and texts were selected initially through their references to broad themes associated with the civic, inspired, domestic, fame, market and industrial worlds. We searched these data sources for keywords associated with each of these 'worlds'; for example, with respect to the inspired world, we examined how the keywords 'inspiration' or being 'inspired' were evidenced and used in these diverse reports.

Second, we then examined more closely how these sources made use of more specific concepts and keywords that are associated with each of the six worlds (as these terms are summarised below in Figure 1). For example, in relation to the inspired world, we examined how keywords such as 'creativity', 'vision', 'genius', 'intuition' and 'spontaneity' were utilised in these texts. We also explored how these concepts and keywords were associated with specific social interests and 
organisations, and with particular justifications or 'worlds' with respect to bidding for or hosting the Olympics. The resulting empirical content provided the basis for our subsequent critical elaboration of Boltanski and Thévenot's theoretical framework, which follows towards the end of this paper.

\section{The Six Worlds of Justification}

The six worlds of justification are briefly summarised in Figure 1. Each world is defined by a set of common criteria, the most important of which are (Boltanski \& Thévenot, 2006, 140-144):

- Higher common principles, or the basis for inclusion within each world;

- States of worthiness, differentiating higher and lower levels of worth;

- Human dignity, or the particular 'common humanity' of each world;

- Lists of subjects who have higher states of worth;

- Lists of worthy objects and arrangements;

- Investment formulas, wherein pursuing worthiness offers particular benefits;

- Relations of worth, differentiating worthiness and unworthiness;

- Natural relations among beings, or hierarchies and equality between people;

- Model tests, or 'peak moments';

- Modes of judgement;

- Forms of evidence that are recognised;

- States of deficiency, failure, decline or 'fall'.

\section{FIGURE ONE ABOUT HERE}

We turn now to summarise these worlds, and then to explore each one with detailed reference to the justifications that are used in bidding for or staging the Olympic Games, primarily the London 2012 event. While being necessarily compact within the confines of a journal paper, our discussion is intended to remain consistent with the orderly, rigorous and systematic approach of Boltanski and Thévenot (2006) in setting out their paradigm.

\section{i) The Inspired World}

Boltanski and Thévenot (2006) present the inspired world as relatively fragile and unstable, and defined by 'the outpouring of inspiration', when spontaneous and transformative experiences ignite profound emotions (excitement, terror, fascination, and so on). They argue that inspiration is driven by love and passion, the 'desire to create', where imagination 'runs wild'. The most inspired are visionaries, blessed with imaginative even magical powers, such as children or artists, living in 'waking dreams', and often criticised as unproductive fantasists. Investment in inspiration centres on evading routines, and accepting risks of failure in pursuit of creative 
success. The inspired judge positively those who are independent, unique, and touched by genius. True inspiration is found or intuited in the masterpiece or 'stroke of genius'; or more commonly in 'unusual ideas', 'images, memories and myths', or fantasies and dreams. Inspired encounters may be mysterious, unexpected and affective, facilitating creativity and originality. Tests of inspiration are adventures, voyages or quests, taking uncertain and wandering paths. Failure or loss of inspiration occurs when people give up dreams, lose originality, slip into routines, 'come back down to earth', and look to 'external signs of success' (such as money or titles).

In bidding for or hosting the Olympics, key organisations reference the inspired world by pointing to a diffuse 'feel-good factor' to be experienced across the city and nation, and to the generalised 'inspirational' qualities of the event (Grix \& Carmichael, 2012). The Olympics are presented as a 'festival', soaked in an atmosphere of celebration that should be experienced rather than watched on television (MacAloon, 1984). At London 2012, the powerful 'feel-good factor' climaxed in a post-Games victory parade by UK athletes through central London; several months afterwards, surveys revealed very high public approval ratings for staging the event (The Guardian, 25 December 2012). References to genius and to powers of inspiration are made on the event's artistic aspects, such as film director Danny Boyle's staging of the London 2012 Opening Ceremony, or the architectural design of Olympic facilities and Olympic-related urban redevelopment (Daily Mail, 27 July 2012; The Guardian, 5 March 2012).

Key organisations seize upon the language of inspiration in two main ways. First, the inspirational Games are claimed to transform ordinary lives. Many London 2012 initiatives emphasised 'inspiration' such as: the Inspire a Generation official slogan, reflecting the aim, in the words of Hugh Robertson, then UK Minister for Sport and the Olympics, to 'harness the power of the Olympic and Paralympic Games to inspire more people into sport' (DCMS 2012: 9); the 'London 2012 Inspire' programme, which sought to inspire community projects (Ferrand et al., 2012, 158-161); and, the 'International Inspiration' campaign, which was intended to inspire sport participation across the world. ${ }^{2}$ The banality of Olympic inspiration was such that one government report on the event made 74 references to 'inspiration' or to being 'inspired' (HM Government/Mayor London Office 2013).

Second, most notably, key organisations utilise the language of inspiration to describe themselves and each other. Representative commissions of the International Olympic Committee (IOC), the Olympic movement's governing body, praised the London 2012 plans as ‘ambitious and visionary', a ‘journey' for the city, and marked by 'passion' (BBC News, 19 February 2005). UK Prime Minister, David Cameron commended the 'inspirational leadership' of the London 2012 organising team (BBC News, 7 November 2012). Some Olympic sponsors also seized the language of inspiration as their own; for example, the Olympic commercial partner, Panasonic,

\footnotetext{
${ }^{2}$ See http://www.internationalinspiration.org/international-inspiration-programme.
} 
claimed to be 'sharing the passion', and spreading the event's 'excitement and thrill' to stadium and global audiences. ${ }^{3}$

The inspired world is challenged by habits, routines and the mundane that deflate the Olympic bubble of excitement. Two key points follow here. First, key organisations may worry that 'iconic' and 'passion-filled' venues are tarnished by dull or decaying surroundings. At London 2012, outside the main Olympic Park complex, the 'scruffy' concrete exterior of a nearby shopping centre was covered over by a huge art installation, featuring dozens of titanium leaves. ${ }^{4}$ The showpiece Olympic Marathon was switched from the planned route around East London, to a more 'inspiring' course through the major sights of Central London (BBC News, 30 May 2011). Second, after the event, the 'return to normal' may lead to a loss of the 'feelgood factor', and to the danger that the Games will fail to 'inspire' the promised social transformations.

\section{ii) The Domestic World}

According to Boltanski and Thévenot, the domestic world is founded upon stable tradition and hierarchy. Superior figures and leaders are the most worthy, characterised by 'good up-bringing', delicacy and firmness towards subordinates, and 'good sense' and bearing towards others. The domestic world resembles households, led by patriarchal figures and is predicated on customs and conventions. Superiors and inferiors are closely interdependent, ensuring future generations are 'well-raised', instilling rules of etiquette and good manners, and principles of pride, honour, respect and shame. Domestic investment bestows individuals with harmonious social relations in return for duties and responsibilities. Peak moments are found in 'family ceremonies' - such as births, deaths and marriages - where individual worth is adjusted or confirmed. Judgement flows from the superior figure, bestowing different levels of trust upon others through appreciation, congratulation, criticism or even contempt. Evidence to back this judgement is provided through anecdotes, examples and cases. Decline or failure in the domestic world occurs when social actors 'lose inhibitions', become indiscreet, gossipy, impolite, and disorderly, or even betray the group's trust.

Key organisations bidding for or hosting the Olympics draw on justifications from the domestic world to appeal to elite hierarchies such as the IOC membership and other authoritative bodies. These justifications appear to take two main forms.

First, bidding cities are expected to show respect for and to celebrate the Olympic 'family' hierarchy. The IOC understands the 'Olympic family' as broadly comprised of the IOC membership, international sport federations, and the National Olympic Committees (NOCs). ${ }^{5}$ To join the IOC, prospective members must be invited to join and to be elected by the existing membership.

\footnotetext{
${ }^{3}$ See http://panasonic.net/olympic/

${ }^{4}$ See http://www.bdonline.co.uk/\%C2\%A33-million-sculpture-to-hide-stratford-eyesore/3158377.article.

${ }^{5}$ See http://www.olympic.org/content/the-ioc/governance/introductionold/
} 
Cities and nations bidding to host the Olympics must fully recognise the domestic world of Olympism. The IOC require bids to meet thousands of special requirements, including provision of many privileges for IOC members or the wider 'Games Family', such as exclusive access to designated Olympic traffic lanes, allocation of cars and drivers to all IOC members, separate airport entrances and exits for IOC members, 'extra late' opening of hotel bars, IOC meeting room temperatures kept at 68F degrees, and relevant hotel furniture having 'Olympic appearance' (CBS Sports, 1 October 2014). In terms of good etiquette, host nations should receive ceremonially the IOC President on airport arrival, while IOC members should be greeted at hotels with smiles from staff (National Post, 2 October 2014).

The 'Games Family' encompasses individuals considered crucial to putting on the event. For London 2012, the approximately 80,000 'Games Family' members included IOC members, sports officials, athletes, sponsors, politicians, celebrities, and media personnel (BBC News, 25 July 2012). At London 2012, the Games Family gained exclusive access to the 'Olympic Route Network': around 109 miles of special road measures, including 30 miles of exclusive road lanes in London (BBC News, 1 February 2012). Corporate sponsors in particular gained tens of thousands of free tickets to the best seats at Olympic venues, prominent advertising spaces, and public messages of thanks from event organisers.

A second way in which the domestic world is referenced relates to peak moments such as the Olympic opening and closing ceremonies. At London 2012, the hierarchies of the Olympic family, and the extended Games Family, were symbolised, for example, through the speeches by the IOC President and other leading officials, declaring the Games open or closed, and passing judgement on the event at its conclusion. The Olympic, national and international domestic worlds also intersect, for example, as top corporate figures, political leaders, royalty, and celebrities are allocated privileged seating positions throughout the event.

Olympism's domestic world encounters several conflicts and tensions. First, Olympic hierarchies may be challenged when these elites fail to receive the 'red carpet treatment'; and, when publics are 'impolite' (such as in not recognising status) or 'impertinent' (such as in criticising special privileges, or staging anti-Olympic protests) towards these figures of authority. Second, the Olympic Family may be threatened through the exposure of IOC members as hypocritical or selfish, such as when bribes are used to influence Olympic voting or in the 'amoral' mistreatment of different athletes (Wenn et al., 2011; Zakus, 1992). Third, organisational blunders during key ceremonies may cause disharmony, for example when the wrong national flags are used during ceremonies, as occurred at a football match involving North Korea at London 2012 (The Telegraph, 25 July 2012).

\section{iii) The World of Fame}

Boltanski and Thévenot (2006) present the world of fame as defined by the 'reality of public opinion', wherein the most worthy have high public exposure, 'self-love' and the 'need' for recognition. They argue that the world of fame is populated by stars 
with distinctive personalities, their fans, and various professional intermediaries (such as journalists, public relations officers) who legitimise this realm. Fame is gained through naming in the media, and pursued through branding, public campaigns, press releases, and opinion surveys. Investment in the world of fame requires participants to reveal their secrets to the public. Relationships of fame are based on being recognised, gaining celebrity status, and influencing or persuading public opinion. Fame is prefigured by the public image and targeting of different audiences. Peak moments or tests occur when social actors are fully in the public eye and in 'presentation' mode. Judgement is provided by public opinion, such as through opinion polls or audience ratings and responses. Falling out of fame sees social actors lose their public image or fade into obscurity.

In bidding for and hosting the Olympics, key organisations use justifications from the world of fame by engaging with global celebrities, mass media, and national governments. Notably, endorsements from world-leading athletes and celebrities are marshalled: at the Singapore IOC vote on awarding the 2012 Olympics, competing cities were backed by sport celebrities such as David Beckham, Sergei Bubka, Raul Gonzalez, and Nadia Comaneci (Guardian, 5 July 2005).

Olympic bidders argue that the globally-televised event may build the 'brand' of the host city, following in particular the 'Barcelona model' to create a leading tourist destination and site for transnational investment (Zhang \& Zhao, 2009; Degen, 2004). ${ }^{6}$ Entering the world of fame is also intended to extend 'soft power': that is, making the host city or nation more attractive and influential within the international community through culture, sport, media, education and the arts (Grix \& Houlihan, 2013; Nye, 2008). In 2012, Monocle magazine ranked the UK at number 1 globally for soft power, in part through staging the Olympics. ${ }^{7}$

'Peak moments', or tests in appeals to the world of fame, occur at times of maximum publicity impact, before global audiences. Examples include the most popular Olympic competitive events, and also opening and closing ceremonies when movie and music stars perform, and VIPs enter the stadium.

Olympic appeals to the world of fame are challenged in two ways. First, Olympic bidders or hosts find themselves in the international media spotlight, and face reputational risk (and loss of soft power) if discrediting reports appear, for example on illegal strategies for winning IOC votes, the abuse of event-related employees, mass evictions of local people to build facilities, or other infringements of civil and human rights (Jennings, 2012; Lenskyj, 2000).

Second, Olympic bidders may also face exclusion from the world of fame. They may lack sufficient glamour or celebrity ties to appeal to IOC members or sponsors. World time-zones may adversely affect prospective television audiences, and thus advertising revenue and actual bids by networks for television rights, particularly in North America and Europe (Larsen \& Park, 1993, 96). In extreme cases, some host

\footnotetext{
${ }^{6}$ See http://www.nielsen.com/us/en/insights/news/2008/beijing-olympics-draw-largest-ever-global-tvaudience.html.

${ }^{7}$ See http://monocle.com/film/affairs/soft-power-survey-2012/.
} 
cities or nations may be boycotted by star athletes, celebrity spectators, and elite competing nations, as occurred at the Moscow 1980 and Los Angeles 1984 Olympics.

\section{iv) The Market World}

The market world is portrayed by Boltanski and Thévenot (2006) as being defined by competition and natural rivalries. They argue that market worthiness is measured through saleable goods that have price or value; the most worthy are rich 'winners' who exploit opportunities and hold the most valuable possessions (goods that sell for high prices). The natural market environment centres on satisfying individual desires and selfish interests, while its key subjects are individual competitors (businessmen, salesmen, buyers, and clients) who pursue wealth and luxury, in the form of desirable and marketable things. Market investment requires opportunism and emotional distance from others. Tests or peak moments in the market world arise in doing the deal; judgement is established through the price, wherein a reasonable value is placed on something or someone; and, evidence is provided in the form of money, 'the measure of all things'. Market decline or failure may be most obviously associated with poverty and financial losses; but, Boltanski and Thévenot highlight instead situations where the 'enslavement to money' takes hold.

Olympic bidders and hosts draw on market world justifications that reflect the particular interests of the national and transnational business sector, along with leading sport federations, including the IOC. These justifications centre on four main points. First, key organisations insist that the Games will be 'good for business', boosting investment, profits, and competitiveness at civic and national levels. For example, the UK government claimed that London 2012 had boosted the national economy by $£ 9.9$ billion (around $£ 1$ billion more than the official stated cost) (BBC News, 19 July 2013). The 'multiplier effect' - which describes how money spent in the host city is recycled, stimulating wider economic activity - is also presented as a market boost for the host city or nation (Goldman Sachs, 2012; Preuss, 2004, 40-44).

Second, Olympic bidders and hosts must justify their aims to market world leaders, specifically the business sector. Multi-tiered partnerships are assembled with leading corporations through the long-running 'Olympic Partner' (TOP) programme, thereby enveloping the event in advertising for prestige brands, while expunging the images and products of rival corporations (Smart, 2007, 128-130; BBC News, 19 July 2012). Olympic venues are often positioned close to major sites of conspicuous consumption, such as the Westfield shopping mall adjoining London's Olympic Park.

Third, construction of Olympic venues and infrastructure is justified as a 'catalyst' for the wider market-driven 'regeneration' of urban areas. For example, at London 2012, public land in East London was cleared and put up for private sale as an investment 'opportunity'; meanwhile, new housing was planned for 'winners' (wealthier social classes), with the strong prospect of raising the locale's socioeconomic profile while squeezing out the poor (Fussey et al., 2011; Lindsay, 2014).

Fourth, bidding cities and nations must demonstrate to the IOC that they are good to 'do business with'. One test here concerns the commitment of bidders to the 
contractual demands of the IOC that any event liabilities will lie with the host city and local organisers (Greenfield et al., 2012, 309).

The market world is challenged or undermined in financial terms. High costs or severe losses may be incurred: most notoriously, from the 1976 Games, Montreal only paid off its CAD\$1.5 billion hosting debt in November 2006 (CBC News, 9 December 2006). Prohibitive spending by some hosts - such as the estimated US\$20 billion for Beijing 2008, or over US\$50 billion for Sochi 2014 - have discouraged some potential hosts from bidding (The Guardian, 28 July 2008; Deutsche Welle, 6 February 2014). Moreover, many economists, politicians, journalists, and local pressure groups have assembled substantial evidence that the Olympic Games cost far more than they earn for host cities (New York Times, 5 August 2014; Zimbalist 2015).

\section{v) The Industrial World}

Defined by science and technology, the industrial world encompasses the efficiency, productivity, reliability and performance of social actors. The worthy control production, while the unworthy are deemed unproductive, inefficient, and lazy. Relationships centre on functions and putting to work different aspects of production. Work represents the natural condition within the industrial world; its main subjects are professionally qualified and hierarchically organised; its objects are the 'means' and instruments or work, such as tools or production methodologies; and, it is exercised through relations of control, and the wider 'functioning of beings' within the industrial process. Investment in the industrial world involves a commitment to progress and development, to avoid obsolescence. Prefigured upon organisational systems and structures, the industrial world has the trial as its peak moment, when new projects are launched, or fresh arrangements made to function effectively. Judgement in the industrial world centres on the question of effective functioning, with evidence involving measurement of performance. The industrial world is endangered when instrumental action leads to people being treated as things, thereby offering strong grounds for criticism of the 'technological society'.

Olympic bidders and hosts draw on justifications from the industrial world that tend to refer to the interests of the IOC, civic or national authorities, the business sector, and to a lesser extent, citizens and communities. Appeals to the industrial world within Olympism take two main forms. First, Olympic bidders and hosts must demonstrate to the IOC their capacity to stage successfully the event. For the 2012 Olympics, the initial nine 'applicant' cities were evaluated according to eleven key criteria, including accommodation, general infrastructure, sport venues, environment, finance, government support and public opinion, Olympic Villages, event legacy, safety and security, and transport. ${ }^{8}$ The top-five cities were invited to become full 'candidate cities', and inspected directly by an IOC 'evaluation commission'. Thus, demonstrating hosting competence requires long-term planning and investment on facilities, infrastructure, security, and project management (DCMS 2012). Event

\footnotetext{
${ }^{8}$ See http://registration.olympic.org/en/faq/detail/id/20.
} 
organisers also seek to persuade the IOC that they can deliver the 'greenest Games' ever, particularly in being 'carbon-neutral' (The Guardian, 15 November 2012). In security, in the post-9/11 context, Olympic and other mega-event hosts must show maximal preparedness in being 'terrorist-ready' and able to 'plan for the worst' potential scenarios (cf. Boyle \& Haggerty, 2012).

Second, Olympic bidders and hosts must demonstrate measurable levels of ambition, in aiming to put on 'the best Games ever' (Kassens-Noor, 2012, 2). Tests of these aspirations lie in the demonstrated functionality and smooth delivery of the event; in 'key performance indicators' such as attendance, television viewing figures, and national team medals; and, in the positive technical judgements of Olympic officials.

Conflicts and weaknesses in the industrial world arise in three main areas. First, efficient, reliable and secure delivery of the event may be threatened: building work is late, transport and media systems break down, or security measures are problematic. For example, two weeks before London 2012, the private security provider G4S confirmed its failure to deliver 10,400 security officials as contracted; to plug the gap, local organisers brought in several thousand military personnel (Financial Times, 17 July 2012). Further major concerns centred on London's busy transport system, and the dangers of massive congestion, railway breakdowns, security delays, and possible industrial action (Giulianotti et al., 2015; Telegraph, 30 April 2012).

Second, wider concerns centre on whether the Olympics will deliver the impacts promised to wider publics, for example in the medal performance of the national Olympic team, a successful and enjoyable event, and broader legacies such as in sport facilities, mass sport participation, education, urban regeneration, and economic growth.

Third, there are potentially dysfunctional aspects of hosting the Games which disrupt the workings of the city or nation, such as causing transport congestion to be endured by commuters, or having businesses and residents served with compulsory purchase or eviction orders in order to make way for construction of event venues (The Guardian, 17 July 2012).

\section{vi) The Civic World}

For Boltanski and Thévenot (2006), the civic world is rooted in the collective or general will, which may lead into a social movement that takes collective action. They state that the worthiest entities within the civic world are representative and rulegoverned collectives, which unify and act for the people. Civic social actors have a 'natural' commitment to political bonds, civil rights, and collective identities, typically within political parties or community associations, as officials, members and delegates. Civic relations are facilitated by legal objects, such as laws, rights, and policies, and forged through assemblies, democratic debate, and collective action. Civic investment requires abandoning individual or sectional interests in favour of the collective. Civic worlds are best illustrated in democracies and republics; their 'peak moments' occur through demonstrations of the collective will and for a 'just cause', 
such as in congresses, assemblies, meetings, and formal disputes. Civic judgement is exercised through the vote, notably at elections, and in collective mobilisations; evidence is most admissible through legal statutes and rules. The civic world crumbles when collective bonds splinter and fragment, elections are invalidated, or individual interests and aspirations take hold.

In bidding to host the Olympics, key organisations utilise civic world justifications when appealing to the collective interest and pursuing support across communities of citizens. The Games' 'unifying' power is highlighted, in crystallising national identity and values, strengthening forms of national and transnational solidarity, while germinating intense senses of communitas within host cities (MacAloon, 1984). The benefits of collective endeavour are evidenced by successful staging of the event and team performances (The Guardian, 8 August 2012). At London 2012, the International Olympic Committee (IOC) President Jacques Rogge and others portrayed the old values of Olympism - such as fair play and sportsmanship - as quintessentially British (The Telegraph, 30 July 2012). The Games were also presented as symbolising the UK as a modern, multi-cultural, diverse and successful nation. Wider civic benefits for staging the event are trumpeted, such as increased mass sport participation, improved public health, better community relations, and a positive transformation of the local environment (The Guardian, 20 March 2012).

The 'test' of civic effectiveness for bidding cities centres on mobilising citizens as supporters of the bid; and, for host cities, as athletes, volunteers (or 'Games makers' in London), spectators, and television viewers. To show that civic support for hosting the event had been mobilised, advocates of the 2012 Games regularly showed images of crowds cheering in the city centre at the moment in July 2005 when the London bid was approved. Yet the strongest civic test lies in winning a full democratic mandate for bidding to host the event, such as through a plebiscite of citizens.

Bidding cities and nations may experience diverse civic conflicts or weaknesses. Public criticism and opposition may be directed at the event for various reasons: perceived high costs, disruption of civic life, damaging impact on local green spaces, weak civic values (such as accountability, democracy, civil rights and human rights), allegations of corruption against Olympic members, and failure to deliver benefits to local people (Jennings, 1996; Lenskyj, 2000; Time, 26 July 2012; Watt, 2013). Public opposition may be manifested through demonstrations, protest movements, opinion polls, or 'no' votes in plebiscites (Giulianotti et al., 2015; Lenskyj, 2008). Key organisations may also fail to mobilise citizens: public apathy or industrial strikes may affect bids or hosting preparations, pre-Olympic events may be performed in halfempty stadia, and low numbers of volunteers may step forward. 


\section{The Three Levels of the Six Worlds}

This analysis of Olympic bidding and hosting enables us to identify how the six worlds of worth are harnessed to advance particular justifications on a prominent public issue. We argue that two key processes - anticipatory justification and multiworld justification - are at play here. First, anticipatory justification occurs at the predispute stage, when social actors anticipate the possibility of critique from the other worlds. These actors will seek to negate potential criticisms in different ways, for example by incorporating some aspects of these possible criticisms into the original justification. Second, multi-world justification arises when social actors seek to justify their interests or intentions with reference to as many worlds and figures of worth as possible. Multiple justifications rarely integrate arguments from all worlds in equal measure; instead, the emphasis is on mixtures of some worlds rather than others.

Strategies of anticipatory and multi-world justification are apparent in how key organisations endeavour to promote Olympic bidding and hosting. But, which worlds and justifications are considered to be the most influential or significant? In our view, these key organisations engage with the six worlds at three very different levels, which are set out in Figure 2.

\section{FIGURE 2 ABOUT HERE}

First, mutual collaboration occurs between the three most influential worlds, namely market, fame and domestic. These worlds justify the ties of Olympism with commercialism, consumerism, and the privatisation of urban spaces (market); celebrity culture, global television audiences, and the pursuit of soft power (fame); and, organisational hierarchies and ceremonies of social standing (domestic). Taken together, the market, fame and domestic worlds represent the hegemonic first level for Olympic hosts and bidders; the most 'worthy' entities here - event organisers, corporate sponsors, political elites in sport and government, and media corporations hold a dominant position vis-à-vis other social groups within the other worlds.

Second, the industrial and inspired worlds represent the second level for Olympic hosts and bidders which undergo processes of colonisation and recuperation by the first level. Thus, the industrial world - referring to delivery of event facilities, infrastructure, security and Olympic performances - is oriented towards meeting the interests of the market, fame and domestic worlds, fulfilling the shared needs of corporations, global media systems, powerful nation-states, and elites within sport governing bodies. The inspired world is recuperated by first-level worlds; thus, we find the artistic language of inspiration, vision, and creativity being directed onto key actors and their organisations within the market, fame, and domestic spheres. 
Third, mobilisation and marginalisation occur for the civic world, through its third level relationship to these other levels and worlds. Depending on context, the dominant first level worlds require to mobilise the civic world in order to bid successfully to stage the Olympics. Such mobilisation of populations is usually undertaken selectively, through staging particular events (such as on the day of the award being made) or through selective types of 'public consultation'. In addition, claims as to the citizen benefits of hosting the event may actually reference worlds other rather than the civic, for example by trumpeting commercial gains (market), international standing (fame), the 'feel-good factor' (inspiration), and so on. Beyond such mobilisation, the main logics of the civic world tend to be marginalised by the first and second levels, partly as civic groups may otherwise seek awkward tests for justifying the Olympics, with reference to principles of public dialogue, accountability, democracy and transparency.

These observations on the first and second level worlds have significant continuities with Boltanski's insights elsewhere. We mentioned earlier the arguments of Boltanski and Thévenot (2006) on the ties between market and industrial worlds. Additionally, Boltanski and Chiapello (2007) indicate that, in effect, the market world has colonised the industrial and inspired worlds to create a 'new spirit of capitalism', as evidenced particularly in commodity production. The vital point here is that industrial capitalism has effectively commodified or recuperated many of the 'artistic critiques' which it had faced. Thus, old, large-scale Fordist hierarchies within workplaces - which were criticised by artists as dull, bureaucratic, depersonalised and alienating - have often been replaced by post-Fordist working networks, which offer employees greater autonomy and creative licence, but much weaker conditions of job security. Significant ties are also identifiable between other worlds: for example, Smart $(2005,10)$ highlights the strong interrelations between 'celebrity culture and commodity culture' - in other words, between the worlds of fame and the market - as illustrated by global sport stars who endorse the products of Olympic sponsors.

\section{The Civic World and Other Worlds: Conflicts and Compromises in Olympism and Beyond}

Our analysis of the three levels of justification points to how vital elements of the civic world are marginalised vis-à-vis other worlds. In the case of Olympism, we see how these other worlds are justified with reference to: traditional hierarchies (IOC membership) in the domestic world; commercial activities (television, sponsorship revenues) in the market world; celebrities and audiences (star athletes, celebrity visitors, multi-billion television viewers) in the world of fame; excitement and spectacle (opening and closing ceremonies, Games planning and implementation) in the inspired world; and, effective delivery and production (secure organisation and delivery of the Games) in the industrial world. 
This marginalisation of the civic world is recognised and contested by active publics. In the case of the Olympic hosting, this contestation on civic grounds is perhaps most strongly illustrated by publics which oppose staging the Games. In response to such critical public opinion, many European cities or nations have abandoned their planned or actual bids for the Olympics. For example, Oslo, Kraków, Munich and Graubünden dropped their initial interest in the 2022 Winter Olympics due to negative public votes or lack of public support; at the final IOC vote for these Games, only Almaty and Beijing remained in contention, partly due to their weak civil societies and records of public consultation.

Arguments from the civic world may take two different, broad positions in response to their marginalisation. The first stance involves critiquing the wider field and key organisations (in this case, Olympism and the IOC) for failing to embrace or institutionalise civic world values. For example, some social critics and civil society organisations contend that civic values (such as in 'human rights') should become the 'fourth pillar' of Olympism, alongside sport, culture, and the environment. ${ }^{9}$

Second, civic world arguments may criticise each of the other five worlds. Boltanski and Thévenot (2006, 251-260) list these five types of civic world criticism. With the exception of the civic critique of the world of fame, each of these criticisms maps directly onto the case of Olympic bidding and hosting. To summarise, according to Boltanski and Thévenot, the civic world criticises:

- The market world for 'market individualism', and representing citizens as 'clients' or consumers. Thus, contemporary Olympic events are criticised for excessive commercialism; commodification of public land and services; and, the eviction, silencing and marginalisation of poor citizens, to make way for 'redevelopment'.

- The domestic world, for paternalism, authoritarianism, corruption, its 'old-boy network', private and insider decision-making, and outbreaks of parochial bickering (Boltanski \& Thévenot, 2006, 251-9). Such critiques highlight the politics of the IOC as undemocratic, having historical connections with oppressive regimes, and broadly against the public interest (cf. Jennings, 1996; Lenskyj, 2000).

- The world of fame which, according to Boltanski and Thévenot (2006, 259), uses opinion polls that capture impressionable individual opinions and interests, and is contrary to the civic collective will, which is otherwise best expressed through elections. However, many cities or nations bidding to host mega-events pay little heed to opinion polls, far less commission plebiscites in order to capture civic approval or disapproval on the issue.

- The industrial world, for 'bureaucratisation' and stultifying education and training. The civic world criticises how Olympic organisers seek to downgrade important political issues (such as transport arrangements, or the clearing of public land) into matters for bureaucratic procedure.

\footnotetext{
${ }^{9}$ See http://library.la84.org/SportsLibrary/ISOR/ISOR2006r.pdf.
} 
- The inspired world, for irresponsible impulsivity and excessive individualism, which undermine collective unity and coordination. In Olympic bidding and hosting, key decision-makers may be criticised for failing to think through the social impacts of their impulse to stage the event, or how state-of-the-art event venues will be used by local publics afterwards.

Conflicts between the civic world and the other worlds may produce compromises, so that a clash is suspended as the rival parties 'agree to settle' (Boltanski, 2012, 57; Boltanski \& Thévenot, 2006, 277). An extensive discussion of these different compromises is set out in On Justification (Boltanski \& Thévenot, 2006, 293-335). To extend this analysis, we may outline how the public issue of Olympic bidding and hosting points to three ways in which civic world compromises with other worlds reflect different balances of power and influence.

First, some compromises tend to advantage the other worlds over the civic world. For example, in relation to Olympic bidding and hosting, the civic/industrial compromise may see large numbers of citizens being mobilised to work as Olympic volunteers, while the civic/fame compromise may involve celebrities being used to attract public interest in the event.

Second, less commonly, some compromises may advantage the civic world in terms of facilitating its critical or radical dimensions. For example, part of the civic/inspired compromise involved the inspiration of creative protests by opposition groups, as occurred when performing artists contributed to anti-Olympic movements and protests at London 2012 (The Guardian, 20 July 2012).

Third, no significant compromises may occur, usually to the advantage of the other worlds. Thus, for example, from the perspective of the civic world, commercial influences remain strongly influential (civic/market worlds); meanwhile, civil rights are weakened, and the IOC and associated organisations remain deeply hierarchical (civic/domestic worlds). In this way, the pre-eminence of the first level of worlds market, domestic, fame - remains intact.

\section{Conclusion: Re-justifying the Civic World}

As we have sought to demonstrate in this paper, Boltanski and Thévenot's theoretical model may be critically applied and extended to examine public issues in sport and elsewhere, with regard to how different worlds of justification are marshalled by social actors, and how particular types of interplay and power differential arise between these worlds. Through discussion of Olympic bidding and hosting, our critical elaboration of this model has centred, first, on forwarding the concepts of anticipatory and multi-world justifications, to capture how social actors both anticipate opposing arguments and appeal across different worlds in order to advance their cases; second, on identifying the three levels of the six worlds, and the particular interrelations of these worlds through processes of mutual collaboration, colonisation, recuperation, mobilisation and marginalisation; and third, on exploring how these 
hierarchies are also reflected in the conflicts and compromises between the civic and other worlds.

We might suggest two fields of future research that have been beyond the scope of this paper. First, future studies may utilise our substantially modified version of Boltanski and Thévenot's framework in order to pursue in-depth comparative analysis of Olympic bids and hosting by different cities and nations. These studies would help to identify similarities and differences between cities and nations in how particular worlds of justification are emphasised or underplayed in proposed bids to host the Olympics, and also in how these bids may be dropped, as witnessed in the case of cities such as Oslo, Krakow, Munich, and Boston.

Second, future work may probe the extent to which bids to host the Olympics may combine 'tests of justification', which are relevant to this paper, with 'tests of strength'. The latter involves the mobilisation of 'any and all kinds of strength... Anything goes, as long as it is crowned with success' (Boltanski \& Chiapello, 2005b, 171). In this sense, the form and content of Olympic bids may be examined with reference to the particularities of the local context, and the varieties and strengths of resistance that arise at different times.

To conclude here, we may build on our discussions of the marginalisation of the civic world to explore how civic justifications may gain a stronger position in public issues. First, most obviously, it is important for constitutional entities and adjudicating bodies - which profess to incorporate the 'common good', while laying the ground-rules for disputes - to recognise the core precepts of the civic world. Additionally, these entities and bodies should ensure that the civic world is central to the justifications and compromise that are advanced by key organisations in public issues in sport and other realms. In the case of Olympics hosting, for example, the IOC should recognise the civic world by requiring cities and nations to conduct public referendums before bidding to host major Olympic events. Certainly, there is the likelihood that many cities or nations will vote 'no'. But then such a public statement should give the strongest entities within the first level of worlds - in this case, the Olympic family, sponsors, celebrities, media, and national governments - cause for reflection on how to produce more justifiable 'compromises' that respect the civic worth.

Second, civic world critiques of the other worlds should lead to cross-world reforms. For example, for the Olympic movement, these civic world critiques should facilitate greater democracy and transparency in how IOC members are elected or Olympic host cities are chosen (impacting upon the domestic world); should reduce the emphasis on profitability, so that, for example, prospective event sponsors undergo more stringent ethical tests (impact on market world); and, should reassert the value of participation vis-à-vis the strong focus on celebrity athletes and spectators (impact on world of fame).

Third, in drawing on Durkheim's moral philosophy, Boltanski and Thévenot (2006, 285) argue that the civic and industrial worlds should operate together in a way that 'shunts aside the market principle'. In our view, this point should be much more 
radically extended, so that the civic world should be placed more centrally in partnerships with other worlds. In this way, the existing hierarchy between the first, second and third levels may be challenged. A civic world that is reinvigorated through recognition by key social actors in any dispute would be well positioned to work alongside reformed versions of the inspired, fame, and domestic worlds, and with more constrained variants of the market world. It would also enable the civic world to feature more fully within the anticipatory and multi-world justifications that groups of influential social actors may seek to make in relation to specific issues.

In establishing these compromises and collaborations, extensive reference will inevitably be made to the 'common good'. In sport, most stakeholders - such as governing bodies, sponsors, athletes, media, governments, spectators and volunteers tend to envision the common good as essentially the domain of international humanity, as instanced for example in the themes of internationalism and peace that envelop every Olympic Games. In the longer-term, this definition of the common good points to how sport may be used to advance the civic world's influence within diverse public disputes. More immediately, the case of Olympism also underlines how the continued marginalisation of the civic world in relation to public issues is essentially unjustifiable, whether in sport or other social realms.

\section{Acknowledgements}

We wish to thank the journal editors and two referees for their helpful comments, criticisms and suggestions on an earlier version of this paper. We thank referee 2 in particular for suggestions in the conclusion here on 'tests of strength'. Also, we would like to thank Gisle Andersen at the University of Bergen, for useful comments on an early draft of the paper.

\section{References}

Bénatouil, T. (1999). A tale of two sociologies: The critical and the pragmatic stance in contemporary French sociology. European Journal of Social Theory, 3(2), 379-396.

Blokker, P. (2011). Pragmatic sociology: Theoretical evolvement and empirical application. European Journal of Social Theory, 14(3), 251-261.

Boltanski, L. (2011). On critique: A sociology of emancipation. Cambridge: Polity.

Boltanski, L. (2012). Love and justice as competences. Cambridge: Polity.

Boltanski, L. \& Chiapello, E. (2005a). The new spirit of capitalism. London: Verso.

Boltanski, L. \& Chiapello, E. (2005b). The new spirit of capitalism. International Journal of Politics, Culture, and Society, 18(3-4), 161-188.

Boltanski, L. \& Thévenot, L. (1999). The sociology of critical capacity. European Journal of Social Theory, 2(3), 359-378.

Boltanski, L. \& Thévenot, L. (2006). On justification: The economies of worth. Cambridge: Polity. 
Boyle, P. \& Haggerty, K. (2012). Planning for the worst: Risk, uncertainty, and the Olympic Games. British Journal of Sociology. 63(2), 241-259.

DCMS (Department for Culture, Media and Sport) (2012). Beyond 2012: The London 2012 legacy story. London: DCMS.

Degen, M. (2004). Barcelona's Games: The Olympics, urban design, and global tourism. In M. Sheller \& J. Urry (.Eds) Tourism mobilities: Places to play, places in play. London: Routledge.

Ferrand, A., Chappelet, J.-L., \& Seguin, B. (2012). Olympic Marketing. London: Routledge.

Fussey, P., Coaffee, J., Armstrong, G., \& Hobbs, D. (2011). Securing and Sustaining the Olympic city: Reconfiguring London for 2012 and beyond. Aldershot: Ashgate.

Giulianotti, R., G. Armstrong, G. Hales, \& R. Hobbs (2015). Sport mega-events and public opposition: A sociological study of the London 2012 Olympics. Journal of Sport and Social Issues, 39(2), 99-119.

Goldman Sachs (2012). The Olympics and Economics 2012. London: Goldman Sachs.

Greenfield, S., James, M., \& Osborn, G. (2012). The Olympics, the law and the contradictions of Olympism. In H. Lenskyj \& S. Wagg (eds) The handbook of Olympic studies. Basingstoke: Palgrave.

Grix, J. \& Carmichael, F. (2012). Why do governments invest in sport? A polemic. International Journal of Sport Policy and Politics, 4(1), 73-90.

HM Government/Mayor London Office (2013). Inspired by 2012: The legacy from the London 2012 Olympic and Paralympic Games, London: UK Government Cabinet Office.

Houlihan, B. \& Grix, J. (2013). Sports mega-events as part of a nation's soft power strategy: The cases of Germany (2006) and the UK (2012). British Journal of Politics and International Relations. Available at: http://onlinelibrary.wiley.com/doi/10.1111/1467-856X.12017/abstract. Accessed on 12 December 2013.

Jennings, A. (1996). The new lords of the ring. London: Pocket.

Jennings, W. (2012). Olympic risks. Basingstoke: Palgrave.

Kassens-Noor, E. (2012). Planning Olympic legacies. London: Routledge.

Larsen, J.F. and Park, H.-S. (1993). Global television and the politics of the Seoul Olympics. Boulder: Westview.

Lenskyj, H. (2000). Inside the Olympic industry. Albany: SUNY.

Lenskyj, H. (2008). Olympic industry resistance. Albany: SUNY.

Lindsay, I. (2014). Living with London's Olympics. Basingstoke: Palgrave.

MacAloon, J. (1984) Olympic Games and the theory of spectacle in modern societies. In J. MacAloon (ed.) Rite, drama, festival, spectacle. Philadelphia: Institute for the Study of Human Issues.

MacRury, I. (2009). Branding the Games: Commercialism and the Olympic city. In G. Poynter \& I. MacRury (eds) Olympic cities: 2012 and the remaking of London. London: Routledge.

Nash, K. (2014) The promise of pragmatic sociology: Human rights and the state. In S. Susen and B. Turner (eds) The spirit of Luc Boltanski. London: Anthem.

Nielsen, M.W. (2014) Justifications of gender equality in academia: Comparing gender equality policies of six Scandinavian universities. NORA - Nordic Journal of Feminist and Gender Research, 22(3), 187-203. 
Nye, J. (2008) Soft power and the Beijing Olympics. Available at: http://www.realclearworld.com/articles/2008/08/soft_power_and_beijing_olympic.ht ml. Accessed on 10 December 2013.

Pecoraro, M.G. \& Uusitalo, O. (2014) Conflicting values of ethical consumption in diverse worlds: A cultural approach. Journal of Consumer Culture. DOI: $10.1177 / 1469540513485273$.

Preuss, H. (2004). The economics of staging the Olympics. Cheltenham: Elgar.

Smart, B. (2005). The sport star, London: Sage/Theory, Culture \& Society.

Smart, B. (2007). 'Not playing around: Global capitalism, modern sport and consumer culture’, Global Networks, 7(2), 113-134.

Susen, S. and Turner, B.S. (.Eds) (2014) The spirit of Luc Boltanski: Essays on the 'pragmatic sociology of critique'. London: Anthem.

Thévenot, L. (2002). Conventions of coordination and the framing of uncertainty. In E. Fullbrook (ed.) Intersubjectivity and economics. London: Routledge.

Thévenot, L., Moody, M., \& Lafaye, C. (2000) Forms of valuing nature: Arguments and modes of justification in French and American environmental disputes. In M. Lamont \& L. Thévenot (eds) Rethinking comparative cultural sociology. Cambridge: Cambridge University Press.

Watt, P. (2013). 'It's not for us': Regeneration, the 2012 Olympics and the gentrification of East London. City, 17(1), 99-118.

Wenn, S.R., Barney, R. \& Martin, S. (2011). Tarnished rings. Syracuse: Syracuse University Press.

Zakus, D. (1992). The International Olympic Committee: tragedy, farce and hypocrisy. Sociology of Sport Journal, 9(4), 340-353.

Zhang, L. \& Zhao, S. (2009) City branding and the Olympic effect: A case study of Beijing. Cities, 26, 245-254.

Zimbalist, A. (2015). Circus maximus. Washington: Brookings Institute.

Richard Giulianotti (PhD Aberdeen, 1996) is Professor of Sociology in the School of Sport, Exercise and Health Sciences at Loughborough University, and also Professor II at the University College of Southeast Norway (Telemark campus). His main research interests are in the fields of sport, globalization, development and peace, sport mega-events, crime and deviance, cultural identities, and qualitative methods. He is author of the books Football: A Sociology of the Global Game (Polity 1999); Sport: A Critical Sociology (Polity 2005; revised edition, 2015); Ethics, Money and Sport (with Adrian Walsh; Routledge 2007); Globalization and Football (with Roland Robertson; Sage 2009); and, Policing the 2012 London Olympics (with Gary Armstrong and Dick Hobbs; Routledge, in press). He has recently edited The Handbook of the Sociology of Sport (Routledge, 2015); he has edited many other books, and published numerous articles in international journals and edited books. His work has been translated and published in a dozen languages.

Loughborough University, School of Sport, Exercise and Health Sciences, Leicestershire, UK, LE11 3TU, Tel. +44 (0)1509 226350

E-Mail: R.Giulianotti@lboro.ac.uk 
Tommy Langseth is Associate Professor in the Department of Sports and Outdoor Life Studies at the University College of Southeast Norway. He holds a Cand. Polit. degree in sociology from the University of Bergen and a PhD from the Norwegian School of Sport Sciences. His recent publications in English include "B.A.S.E. jumping: beyond the thrills", European Journal for Sport and Society (2012) and "Liquid ice surfers: the construction of surfer identities in Norway”, Journal of Adventure Education and Outdoor Learning (2012). Langseth's research has focused upon processes of recognition in sport subcultures and the social aspects of risk taking.

University College of Southeast Norway, Faculty of Arts and Sciences, Department of Sports and Outdoor Life Studies, Hallvard Eikas plass, N-3800 Bø i Telemark, Norway. Tel: + 47 35952760

E-Mail: Tommy.Langseth@hit.no 
Figure 1: Six Orders of Worth in Boltanski \& Thévenot (2006)

\begin{tabular}{|c|c|c|c|c|c|c|}
\hline & $\begin{array}{l}\text { Inspired } \\
\text { World }\end{array}$ & $\begin{array}{l}\text { Domestic } \\
\text { World }\end{array}$ & $\begin{array}{l}\text { World of } \\
\text { Fame }\end{array}$ & Market World & Industrial World & Civic World \\
\hline $\begin{array}{l}\text { Higher } \\
\text { common } \\
\text { principle }\end{array}$ & Inspiration & Tradition & Public opinion & Competition & Efficiency & Collective will \\
\hline $\begin{array}{l}\text { States of } \\
\text { worthiness }\end{array}$ & $\begin{array}{l}\text { Spontaneity, } \\
\text { emotion }\end{array}$ & $\begin{array}{l}\text { Hierarchical } \\
\text { superiority }\end{array}$ & Fame & $\begin{array}{l}\text { Value, } \\
\text { winning }\end{array}$ & Efficient, reliable & Representation \\
\hline $\begin{array}{l}\text { Human } \\
\text { dignity }\end{array}$ & Creativity & Habit & $\begin{array}{l}\text { Desire } \\
\text { recognition }\end{array}$ & $\begin{array}{l}\text { Interest, } \\
\text { selfishness }\end{array}$ & Work & Civil rights \\
\hline $\begin{array}{l}\text { Worthy } \\
\text { subjects }\end{array}$ & Visionaries & $\begin{array}{l}\text { Superiors, } \\
\text { inferiors }\end{array}$ & Stars, fans & Competitors & $\begin{array}{l}\text { Professionals, } \\
\text { experts }\end{array}$ & Collectives \\
\hline $\begin{array}{l}\text { Worthy } \\
\text { objects }\end{array}$ & $\begin{array}{l}\text { Waking } \\
\text { dreams }\end{array}$ & Etiquette & $\begin{array}{l}\text { Named in } \\
\text { media }\end{array}$ & Wealth, luxury & Means, tools & Laws, rights \\
\hline $\begin{array}{l}\text { Investment } \\
\text { formulas }\end{array}$ & $\begin{array}{l}\text { Escape } \\
\text { habits }\end{array}$ & $\begin{array}{l}\text { Reject } \\
\text { selfishness }\end{array}$ & $\begin{array}{l}\text { Reveal } \\
\text { secrets }\end{array}$ & Opportunism & Progress & $\begin{array}{l}\text { Renounce } \\
\text { sectionalism }\end{array}$ \\
\hline $\begin{array}{l}\text { Relations of } \\
\text { worth }\end{array}$ & $\begin{array}{l}\text { Uniqueness, } \\
\text { genius }\end{array}$ & $\begin{array}{l}\text { Respect, } \\
\text { responsibility }\end{array}$ & Recognition & Possession & Control & Membership \\
\hline $\begin{array}{l}\text { Natural } \\
\text { relations }\end{array}$ & $\begin{array}{l}\text { Unexpected } \\
\text { encounters }\end{array}$ & $\begin{array}{l}\text { Well-raised } \\
\text { people }\end{array}$ & Influence & Business & Function & $\begin{array}{l}\text { Democratic } \\
\text { assembly }\end{array}$ \\
\hline $\begin{array}{l}\text { Test, peak } \\
\text { moment }\end{array}$ & $\begin{array}{l}\text { Adventures, } \\
\text { voyages }\end{array}$ & $\begin{array}{l}\text { Family } \\
\text { ceremonies }\end{array}$ & $\begin{array}{l}\text { Presentation } \\
\text { to audience }\end{array}$ & Deals & Trial & $\begin{array}{l}\text { Demonstration } \\
\text { for just cause }\end{array}$ \\
\hline $\begin{array}{l}\text { Modes of } \\
\text { judgement }\end{array}$ & $\begin{array}{l}\text { Stroke of } \\
\text { genius }\end{array}$ & Trust & Public opinion & Price & Effectiveness & Vote \\
\hline $\begin{array}{l}\text { Forms of } \\
\text { evidence }\end{array}$ & Intuition & Anecdotes & Being known & Money & Measurement & Laws, rules \\
\hline $\begin{array}{l}\text { Deficiencies, } \\
\text { falls }\end{array}$ & $\begin{array}{l}\text { Come back to } \\
\text { earth }\end{array}$ & $\begin{array}{l}\text { Impolite, } \\
\text { Treasonous }\end{array}$ & $\begin{array}{l}\text { Lose image, } \\
\text { obscurity }\end{array}$ & $\begin{array}{l}\text { Enslavement } \\
\text { to money }\end{array}$ & $\begin{array}{l}\text { Instrumentality, } \\
\text { 'treat people as } \\
\text { things' }\end{array}$ & $\begin{array}{l}\text { Divisions, } \\
\text { individualism }\end{array}$ \\
\hline
\end{tabular}

Adapted from Boltanski \& Thévenot (2006: 159-211). 
Figure 2: Three Levels of the Six Worlds

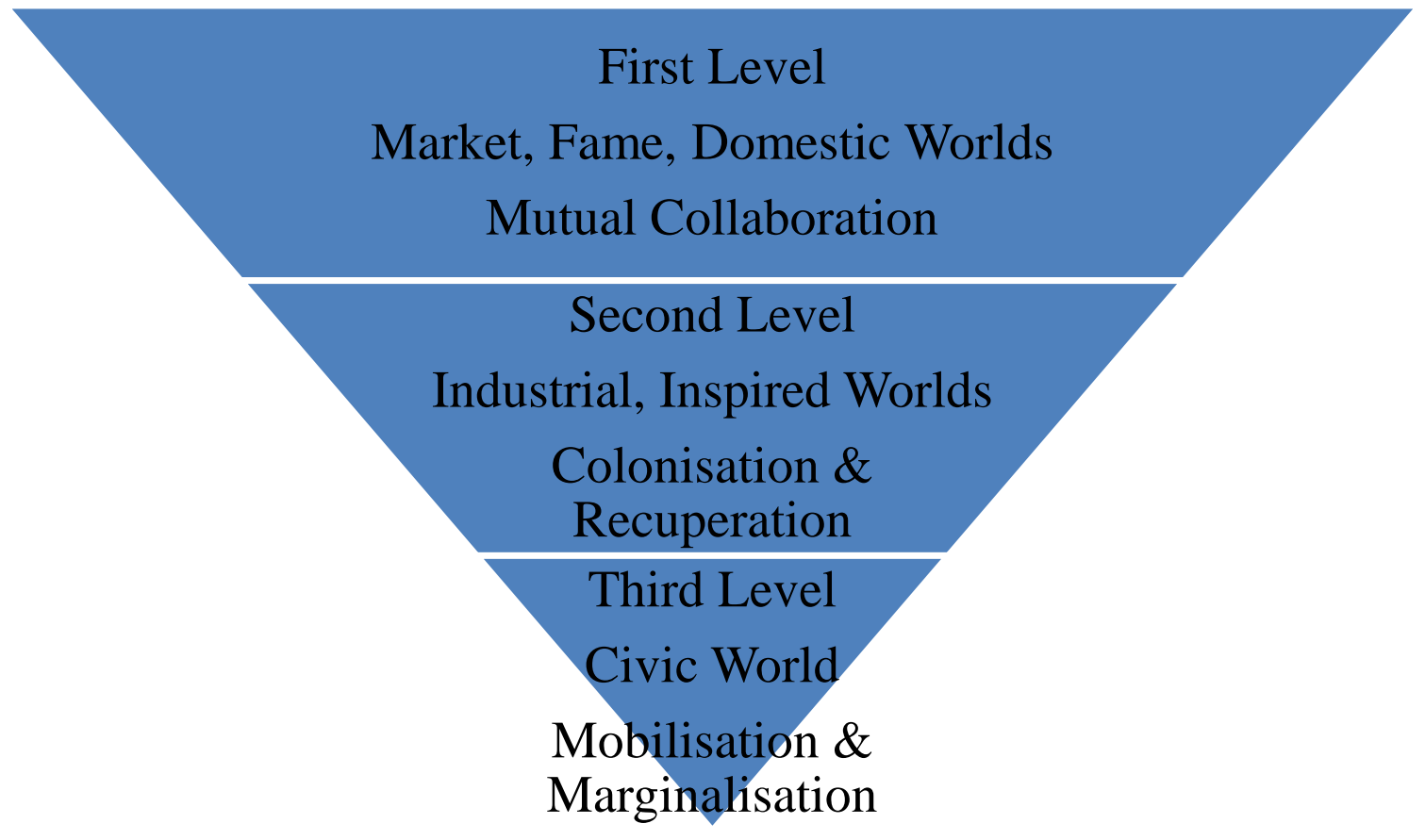

